\title{
Causal Relationship between Industrial Action and Economic Growth in Nigeria
}

\author{
Lydia Bose Jolayemi, Osuolale Fatomilola \\ Department of Economics, Kings University Ode-Omu, Osun State, Nigeria \\ Email: abose76@yahoo.com, o.fatomilola@kingsuniversity.edu.ng
}

How to cite this paper: Jolayemi, J.B. and Fatomilola, O. (2020) Causal Relationship between Industrial Action and Economic Growth in Nigeria. Open Access Library Journal, 7: e5308.

https://doi.org/10.4236/oalib.1105308

Received: March 5, 2019

Accepted: May 16, 2020

Published: May 19, 2020

Copyright $\odot 2020$ by author(s) and Open Access Library Inc.

This work is licensed under the Creative Commons Attribution International License (CC BY 4.0).

http://creativecommons.org/licenses/by/4.0/

(c) (i) Open Access

\begin{abstract}
The paper examines the direction of causality between industrial action and economic growth in Nigeria over the period 1986-2018 using endogenous growth model. This was with the view to determining whether or not manday-lost to industrial crisis in the country through high numbers of industrial action Granger caused economic growth in Nigeria. Annual time series data such as man-day-lost, Gross Domestic Product, Consumer Price Index, Labour Force Participation and Gross Capital Formation were source from Central Bank of Nigeria Statistical Bulletin, National Bureau of Statistics Annual Reports and World Bank Development Indicators. Data were analysed using co-integration and Vector Error Correction Model Granger causality techniques. Results reveal that there exists long-run relationship between industrial action and economic growth in Nigeria. The causality test revealed unidirectional causality running from economic growth to industrial action, while it finds no empirical support for the reverse causation. This implies that whenever economy is growing, citizen may agitate for higher wage increment and thereby leads to higher industrial action in the country. The study concluded that, there exist long-run causal relationship between industrial action and economic growth in Nigeria.
\end{abstract}

\section{Subject Areas}

Economics

\section{Keywords}

Industrial Action, Strikes, Economic Growth, Man-Day Lost, Granger Causality

\section{Introduction}

Over the years, Nigeria has witnessed a sizeable magnitude of labour agitations 
in virtually all sectors of the economy. In recent time, industrial action has become a serious phenomenon in the country to the extent that the economy is often plunged into economic chaos with incessant strike actions by workers in various sectors of the economy. In January 2012, the Nigerian Labour Congress (NLC) embarked on industrial action due to the removal of fuel subsidy and the consequent hike in fuel price. Similarly, is has become a yearly concern that, members of the Academic Staff Union of Universities (ASUU), will embark on the industrial action. For instance, there have been yearly demands by ASUU from federal government since 2013 till this very moment. The recent ongoing ASUU strike since November 4, 2018 has lasted for months without positive response from the federal government on their demands. No doubt, this current ASUU strike may set back the level of education in the country than ever. Its counterpart, Academic Staff Union of Polytechnics (ASUP), went on strike for a period of six months and one year, respectively, the was why huge fear occupied the mind on the student when ASUP declared embarking on indefinite strike in December 12, 2018, as this may be causing set back in the tertiary institution and other related sectors. Recent industrial action by the Joint Health Sector Union (JOHESU) started in November, 2014 but called off in February, 2015 affected the activities and welfare of the citizen. In the same year, the Judiciary Staff Union of Nigeria (JUSUN) embarked on industrial action which lasted for about 2 months. Also, industrial actions embarked on by Nigeria union of petroleum and natural gas workers (NUPENG) and the petroleum and natural gas senior staff association (PENGASSAN) in May 2015 cut across all the sectors in the country. Hence, whenever any sensitive sectors like these embark on industrial action it usually affects the economy as a whole.

Industrial conflicts in Nigeria have become rampant with various degrees of impacts. The recent cases of labour unrest in the country were a source of worry to all Nigerians as it has the potential to undermine the peace and stability of the nation. Anytime a group of workers decide to lay down their tools, in demand for enhanced conditions of service, it becomes difficult to quantify the financial and economic cost to the nation. Though, some studies have been carried out on industrial action and economic growth relationship, especially in Nigeria.

This strike action has been reoccurring in the country up till now which is yet to be resolved virtually in every sector. For the very first time in the history, during the NLC general strike in which sectors such as; banks, communication, education, transportation and others sectors could not function properly simply because there was a scarcity of fuel in the country while the black markers hoarded the little available fuel and sell at a very high price which seems to be unbearable to the citizen. This, off-course not surprising, as similar events happened which led Nigerian Labour Congress on Monday May 2015, announced that 19 states out of the 36 states in Nigeria owned workers' salary which prompted some states like Osun, Oyo, Ekiti, Benue and others to embark on indefinite strike and vowed not to resume until the backlog of the salaries arrears is paid. It then becomes pertinent to ask whether low growth rate experienced in 
Nigeria accountable for persistent increase in the industrial crisis witnessed by all sectors in the country.

Industrial action leading to strike could have adverse effect on economic growth as observed by Akkerman (2014) [1]; Akanbi and Akinlo (2017) [2]. Each time strike occurs substantial man-day is lost as activities of banks, schools, hospitals and other essential sectors are paralyzed. The lost due to strike could have serious implication on economic growth. While evidences from the literature reveal that a large quantum of studies exists on effect of industrial action on economic growth, most of the studies focus on developed countries. Such studies include Snyder (1975) [3], Ann and Nelson (2004) [4], Geraghty and Wisemen (2008) [5], and Chan (2009) [6]. The few empirical studies on Nigeria are centred on either the possible causes of industrial action in the country (Ige, 1998 [7]; Owoseni 2007 [8]; Osabuohien and Ogunrinola 2011 [9]), or on the effect of industrial actions on productivity in some selected sectors of the economy (Osabuohien, 2009 [10]; Okuwa and Campbell, 2011 [11]; and Agba et al., 2012 [12]). The most recent work relating to the subject matter was done by Ezeagba (2014) [13], who only presented the theoretical argument without empirical verification. In the view of Akanbi and Akinlo (2017) [2], the authors only examine the effects of strike action on economic growth in Nigeria without addressing the issue of causal relationship.

Studies on causal relationship between industrial action and economic growth are indeed sparse. Doubtless, some countries or set of countries exhibit more number of industrial actions than some others, while literature have shown that the level of strike activities vary within rapidly industrialized countries Galambos and Evan (1966) [14]; Douglas (2014) [15]; and Kyuhan (1993) [16]. Existing studies attempt to explain and compare the effect of industrial conflict on sectors and countries, but the paucity of studies on the causality between industrial action and economic growth is obvious in the literature. From existing literatures, in Nigeria, Ige and Sowunmi (2012) [17] investigated causality between the number of trade disputes and the consumer price while the causality between industrial action and economic growth is yet to be addressed. Therefore, this paper takes up the challenge to examine causal link between industrial action and economic growth in Nigeria. The need to carry out this research work cannot be overemphasised in view of the on-going political unrest, man-days lost, and increasing unemployment, slow growth among other factors arising from industrial conflicts. Hence, this paper intends to investigate the direction of causality between industrial action and economic growth in Nigeria, thereby presenting justification to the conflicting results in the literature on the strike action-economic growth nexus. Considering only effects of industrial action on sectors and economic growth may be misleading without critically examining the causal links between these variables that the current study analyses.

In addition to introductory section, this paper is organized into four other sections. Section 2 focuses on the review of relevant empirical literature on studies on industrial action-economic growth nexus in both developed and develop- 
ing countries including Nigeria. Model specification and methods of analysis on direction of causality between industrial action and economic growth are presented in Section 3. Section 4 presents the analysis of results while Section 5 summarizes the conclusions of the paper.

\section{Review of the Literature}

Scholars have tried to examine the industrial action cum economic growth in some developed and developing countries. Douglas (1976) [15] examined industrial conflict in advanced industrial societies by investigating the movement of strike among western countries like United State, Sweden, Netherlands, and United Kingdom using descriptive method. The evidence developed shows that strike activities can vary from country to country base on their level of development. That is, countries have widely different industrial relation system which makes significant influence on their ability to reduce industrial unrest, as it in Diduch (1998) [18]. For instance, in Great Britain, where there is a close organic relationship between trade union and labour party elites, the vast majority of strike action is illegal, just like as it was in the United State. It is in a reduce form compared to the scenario in Canada, and some continental European countries (Greenbaum 1972 [19] and Weil, 1973 [20]). The views of these authors are in line with the work of Weil, 1973 [20]) who observed the trend of strike action in Netherlands and France using table and chart. The study concludes that labour conflict occurs about 28 times in France than in the Netherlands. By implication, strike activity is higher in France than in Netherland due to institutional differences.

Moreover, Ann and Nelson (2004) [4] tested the relationship between working day lost and a series of macroeconomic variables for the period of 1985 to 2003 for Australia. These authors adopt both descriptive and econometric technique and also incorporate some microeconomics variables into the model in examining the effect of working day lost in Australia. VECM and VAR analyses were conducted. The ensuing power shift and reduced influence of the union movement in determining the basis of wage negotiations would be expected to lead to increase in strike action. The result supported the view of Douglas (1976) [15], that institutional factors rather than economic condition influence the number and frequency of industrial actions using descriptive method. Studies like Beggs and Chapman, (1987) [21], Morris and Wilson (1994) [22], have demonstrated that the accord process between employees and employers resulted in substantial reductions in strike action and working days lost from industrial conflict.

Whereas the long-run reduction in disputes occur when trade union are incorporated into managerial and government decision making processes, particularly those which address problems such as high inflation, unemployment and adjustments to expanding international trade. Bhorat, Jacob and Westhuizen (2013) [23] established positive relationship between the number of industrial 
disputes and the level of employment protection in the labour market, using an Augmented Lazear Model, where a two-stage endogeneity-corrected least-square model is used to predict the impact of differentially measured indices of industrial disputes in South Africa. Bhorat et al. (2013) [23] suggested that an increase in industrial disputes, measured by the number of industrial dispute cases and the efficiency level decreases regional-level employment.

Meanwhile, Seniwoliba (2013) [24] examined the trend and pattern of strike in Ghana and finds that there must be a greater awareness of worker's needs, values and objectives and management should be more proactive in order to prevent industrial disputes in the economy. However, in the view of Seniwoliba (2013), who regarded the causes of industrial conflict to government policy contrary to some other scholar's view. The author established a more generalized framework of government policy to explain the variation of industrial conflict by expanding observations beyond Organization for Economic Cooperation and Development (OECD) countries and adopted descriptive methods. The result shows that the degree of government intervention in industrial relations has a superior explanatory power in determine the variations of industrial dispute.

In the literature, most of the industrial conflicts occurred as a result of breakdown in negotiation that was traceable to economic issues in Nigeria. Owoseni (2007) [8] found a negative relationship between unemployment and incidence of strike, while Bhorat et al. (2013) [23] in a similar study on the South African labour market establish a positive relationship between industrial conflict and employment protection.

Odeku (2014) [25], explained that the rights of other parties who are not on strike are as important as the right of the striking workers and government should find a means of reducing the numbers of time workers embark on strike because of its consequences on the economy. Using models of relational contract framework and wage bargaining, Ana and Vincent (2002) [26], and Robert and Sala-i-martin (2009) [27], showed that an employee has private information about firm's profitability, and thereby proposes a request (higher salary) which may have outsourced their productions and when such demand is not fulfilled, it often results into slowdown effect or strike action.

The impact of trade disputes and settlement mechanism in Nigeria was examined by Anyim et al. (2012) [28]. The authors observed that in spite of the statutory mechanisms put in place to mitigate disputes, the phenomenon has been on increase on a consistent basis. Ige (1998) [7], examined the factors influencing industrial conflicts in the Nigerian economy using the Ordinary Least Square (OLS) technique to show that wages, price expectation and union concentration have a significant influence on the strike. Ige and Sowunmi (2013) [29], used cointegration approach, found a significant positive causal relationship between the number of trade disputes and consumer price index. The author only considered the causality between trade disputes and consumer price index. Fajana (2006) [30] observed that industrial conflicts can result from a 
number of issues rather than a single one and that the actual occurrence depends on some prevailing circumstances.

Oyeniran (2013) [31] examined the causes and implications of education worker's strike with a particular focus on ASUU strike. The author explains various man-days lost due to strike action, as well as the consequences on the economy, although not subjected to scientific verification. In the same vein, Okuwa and Campbell (2011) [11] worked on the influence of strike on the choice of higher education demand in Oyo State, using statistical methods, result showed that $80 \%$ of households sent their children to private higher institutions irrespective of the price/cost because of frequent strike actions in the public institutions. The author concluded that, no doubt, strike action affects the cost of production and productivity. Also, wages and salaries as well as other avoidable costs in a non-strike situation are incurred during strike periods.

Omotosho (2007) [32] examined privatization and challenges of workers' welfare, using a case study of PHCN workers in Ado Ekiti and reported that the implications may not be easily quantifiable because several sectors would have been affected. While Ezeagba (2014) [13] adopted the Solow model and specifies cost of strike in the production function submits that though industrial conflict is inevitable, strike action can be avoided with good industrial relations.

Ajayi (2014) [33] examined Academic Staff Union of Universities (ASUU) strikes and academic performance of students in Ekiti State University (EKSU) Ado-Ekiti. The author employed multistage sampling technique to select the faculties and the departments from where six hundred and four (604) respondents were selected. Questionnaires and interviews were employed to draw information from respondents. Findings showed that the incessant strikes actions by ASUU in Nigeria have disrupted the academic calendar of Universities and this has affected students' academic pursuit and performance. Result showed that ASUU strikes have had negative influence on their academics.

On industrial conflicts and health care provision in Nigeria, Osabuohien (2009) [10], find that, the value for man-day-lost increased yearly in Nigeria and can be traced to strike action engaged by health practitioners in Nigeria as a measure of the disposition of the Nigerian government towards the health sector. Also, Agba, Ogaboh and Ushie (2012) [12], examined medical and Para-medical staff perception of the impact of wage differential on industrial disputes in Nigerian hospitals. Taking sample of 1109 respondents was purposively selected from Primary, Secondary and Tertiary hospitals in South-South Geo-political Zone of Nigeria (SSGZN). Information was elicited from respondents via structured questionnaire. The author used Pearson product moment correlation coefficient (r) and multiple regressions analysis to analyse the data generated. Results indicated that wage differentials in terms of basic salary, hazard and fringe benefit allowance significantly influenced industrial disputes in Nigerian hospitals. The study further revealed that socio-demographic predictors such as sex, age, category of staff and so on could trigger preferential treatment among the staff and therefore resulted into industrial disputes in Nigerian hospitals so as to curtail 
the discrimination. Whenever industrial conflict occurs, the employer suffers substantial financial losses in terms of lost revenue, loss resulting from decline in productivity, extra cost of hiring labour, and declines in profits among others. The existing studies fail to examine the direction of causality between industrial action and economic growth but focused majorly on the causes and effects of strike on macroeconomic variables.

\section{Model Specification and Method of Analysis}

\section{1) Causality between Economic Growth and Industrial Action Model Speci-} fication

In order to determine the direction of causality between industrial action and economic growth, this study adopted the Vector Error Correction Model (VECM) discussed by Hurlin and Venet (2001) [34]. The model can be written in a more functional form as:

$$
\ln y=f(I A, I N F, k, h)
$$

Following the general contention in econometrics literature that, a cointegrated VAR with non-stationary time series is best estimated with VECM technique, especially in determining the short-run dynamic interaction among set of macroeconomic variables from the cointegrating (long-run) equation. A dynamic model using the Vector Error Correction Model (VECM) representation of Engle and Granger (1987) [35] is applied for this study.

Equation (3.1) becomes;

$$
\begin{aligned}
& \Delta \ln y=\gamma_{1 A 0}+\gamma_{1 A 1} \Delta \ln (I A)+\alpha_{1} \Delta \ln (k)+\beta_{1} \Delta \ln (h)+\delta_{1}(I N F)+e_{1 t} \\
& \Delta \ln I A=\gamma_{2 A 0}+\gamma_{2 A 1} \Delta \ln (y)+\alpha_{2} \Delta \ln (k)+\beta_{2} \Delta \ln (h)+\delta_{2}(I N F)+e_{2 t}
\end{aligned}
$$

For simplicity and in a more statistical presentation, $\gamma_{1 A 0}, \gamma_{1 A 1}, \alpha_{1}, \beta_{1}$ and $\delta_{1}$ used as parameter above becomes $\alpha_{0}-\alpha_{4}$ in Equation (3.2) and $\gamma_{2 A 0}, \gamma_{2 A 1}, \alpha_{2}$, $\beta_{2}$ and $\delta_{2}$ becomes $\beta_{0}-\beta_{4}$ in Equation (3.3);

$$
\Delta \ln y=\alpha_{0}+\alpha_{1} \Delta \ln I A+\alpha_{2} \Delta \ln k+\alpha_{3} \Delta \ln h+\alpha_{4} I N F+e_{1 t}
$$

Thus, to determine the direction of causality between industrial action and economic growth, model of Vector Autoregressive (VAR) representation of Engle and Granger (1987) [35] is be applied, Equation (3.2) and Equation (3.3) can be re-expressed, respectively, as Equation (3.5) and Equation (3.6):

$$
\begin{aligned}
\Delta \ln y= & \alpha_{10}+\sum_{j=0}^{p} \phi_{j} \ln \Delta I A_{t-j}+\sum_{j=0}^{p} \psi_{j} \Delta \ln k_{t-j}+\sum_{j=0}^{p} \tau_{j} \Delta \ln h_{t-j} \\
& +\sum_{j=1}^{p} \lambda_{j} \Delta \ln y_{t-j}+\sum_{j=0}^{p} \delta_{j} \Delta I N F_{t-j}+\pi_{1} E C T_{t-1}+e_{1 t} \\
\Delta \ln I n I A= & \alpha_{20}+\sum_{j=1}^{p} \phi_{j} \Delta \ln I A_{t-j}+\sum_{j=0}^{p} \psi_{j} \Delta \ln k_{t-j}+\sum_{j=0}^{p} \tau_{j} \Delta \ln h_{t-j} \\
& +\sum_{j=0}^{p} \lambda_{j} \Delta \ln y_{t-j}+\sum_{j=0}^{p} \delta_{j} \Delta I N F_{t-j}+\pi_{21-T} E C T_{t-1}+e_{2 t}
\end{aligned}
$$

where $\Delta$ denote first difference and $p$ is the lag length, $\ln$ is the natural loga- 
rithm. The Schwarz Information Criterion (SIC) is used to select the optimal lag length for each of the variable in this paper because it imposes strict penalty on the component of a model than other criteria (Lütkepohl, 2005) [36]. The one period lagged error-correction term, $E C T_{t-1}$ is expected to emerge from the cointegration equation.

The operational definitions of the series employed are:

$y$-(economic growth) is measure by gross domestic product (GDP);

$I A-$ (industrial action) is measured by Man-day lost (MDL);

INF-(inflation) is measured by consumer price index (CPI);

$k$-(physical capital) is measured by gross capital formation (CPF);

$h$-(human capital) is measured by labour force participation (LFP).

\section{2) The Estimation Techniques}

The annual time series data employed in the estimation of the Equations (3.5) and (3.6) covers the period of 1986 to 2016. Data were gathered mainly from the Statistical Bulletin published by the Central Bank of Nigeria (2013) and National Bureau of Statistics Annual Reports. The properties of the time series were first examined in order to avoid cases of spurious regressions Engle and Granger (1987) [35] and Johansen and Juselius (1990) [37]. Both the Augmented DickeyFuller (ADF) and Phillip-Perron (PP) unit root tests were applied to each of the time series.

Following the unit test reports, cointegration tests were conducted. The intuition behind cointegration is that even if time series are non-stationary, there may exist set of linear combinations of such time series that are stationary. Cointegration tests were applied to the residuals of the static long-run regressions with the use of $\mathrm{ADF}$ and PP tests. If the cointegration exists among the time series, then the deviations from the long-run path are stationary and this implies the existence of a long-run relationship among the variables. The model used is an unrestricted VAR model that includes cointegrating relationship among the model, therefore employed Granger causality test to estimate the long-run causal relationship among the variables.

\section{Presentation and Interpretation of Results}

\section{1) Unit Root and Residual Cointegration Test Results}

The results of the unit root tests are reported in Table 1. The results showed that economic growth, strike action, human, consumer price index and physical capital are stationary at first differencing indicating that all the variables are integrated of order one, I (1). The evidence of unit root results provided us with the insight in conducting cointegration for the series. The results indicate that there may be cointegration among the series, especially industrial action and economic series. Furthermore, the use of the levels of these series for modelling will result in spurious result; hence the need to test for the existence of cointegration between economic growth series and its identified explanatory series including strike action. 
Table 1. Unit root test results.

\begin{tabular}{ccccccc}
\hline \multicolumn{3}{c}{ Augmented Dickey-Fuller (ADF) Test } & \multicolumn{3}{c}{ Phillips-Perron (PP) Test } \\
\hline Variables & Level & $\mathbf{1}^{\text {st }}$ Difference & Status & Level & $1^{\text {st }}$ Difference & Status \\
\hline $\log (\mathrm{Y})$ & -1.537659 & $-5.268423^{*}$ & $1(1)$ & -2.211996 & $-5.341840^{*}$ & $1(1)$ \\
$\log (\mathrm{MDLN})$ & -2.630823 & $-5.578805^{*}$ & $1(1)$ & -2.596900 & $-6.930010^{*}$ & $1(1)$ \\
$\log (\mathrm{GCF})$ & -0.121137 & $-4.982040^{*}$ & $1(1)$ & -0.368917 & $-5.944080^{*}$ & $1(1)$ \\
$\log (\mathrm{CPI})$ & -2.951035 & $-4.363159^{*}$ & $\mathrm{I}(1)$ & -2.886481 & $-4.506176^{*}$ & $\mathrm{I}(1)$ \\
$\log (\mathrm{LFP})$ & 0.587792 & $-5.245912^{*}$ & $1(1)$ & 0.869873 & $-5.395660^{*}$ & $1(1)$ \\
$\mathbf{5 \%}$ Critical V. & -2.976263 & -2.981038 & & -2.976263 & -2.981038 & \\
ECM & -4.652177 & $5 \%$ Crittical value $=-1.953858$ & & $\mathrm{I}(0)$ & \\
\hline
\end{tabular}

ADF: automatic maximum lag length based on Schwarz Information criterion; PP: automatic maximum lag length based on Newey-West Bandwidth criterion.

In addition, the reported ADF unit root test statistics on the residuals series (ECM) indicates that ECM is stationary at levels. The stationarity of the ECM series corroborating the possibility of existence of long-run relationship among the variables is presented in Table 1 , where the value of ECM is negative and significant as expected. All the series are at $5 \%$ level of significance.

\section{Johansen Cointegration Test}

The trace statistic shows that there are at least two cointegrating relationships among the variables (Table 2(a)). The unrestricted cointegration Max-Eigen value statistics reports that there is only 1 cointegrating equation at $5 \%$ level (Table 2(b)). This implies that the variables have long-run relationship, suggesting that there is presence of long-run feedback effects on the short-run dynamics of the specified model and the likelihood of Granger causality.

\section{2) VECM Granger Causality Tests}

Causality between industrial action and economic growth in Nigeria was investigated using VECM Granger Causality test. The cointegration tests conducted in this study have shown that, there exist at least two cointegrating equations among the incorporated series (Max-Eigen). This implies that there exist long-run relationships among the variables included in the estimated VECM models in Nigeria for the period under review. The results of the estimated Granger Causality/Block Exogeneity Wald Tests were presented in Table 3.

Table 3 presents the results of VECM Granger causality/Block exogeneity Wald tests. The results show the presence of causality among the included variables. In the first column of the table, the result reveals that causality runs from labour force participation to economic growth at $1 \%$ level of significance (LFP $\rightarrow$ $\mathrm{Y}$ ), while there is no sign of causality from other variables. This implies that human capital is an important variable in promoting economic growth as reported earlier. The second column of the table shows that LFP Granger causes economic growth at $\mathrm{p}<0.01$ level of significance $(\mathrm{Y} \rightarrow \mathrm{LFP}$ ). Thus, there exists bi-directional causality between labour force participation and economic growth. That is as economic growth Granger causes Labour force participation, so also 
Table 2. (a) Johansen cointegration test: unrestricted cointegration rank test (trace); (b): Johansen cointegration test: unrestricted cointegration rank test (Maximum eigenvalue).

(a)

\begin{tabular}{ccccc}
\hline Hypothesis No of CE(S) & Eigenvalue & Trace Statistics & 5\% Critical Value & Prob** \\
\hline None $^{*}$ & 0.932780 & $122.4928^{* *}$ & 69.81889 & 0.0000 \\
At most 1 & 0.608130 & $52.29856^{*}$ & 47.85613 & 0.0180 \\
At most 2* & 0.560634 & $27.94108^{* *}$ & 29.79707 & 0.0806 \\
\hline
\end{tabular}

(b)

\begin{tabular}{ccccc}
\hline Hypothesis No of CE(S) & Eigenvalue & Max-Eigen Statistics & 5\% Critical Value & Prob \\
\hline None* & 0.932780 & $70.19424^{* *}$ & 33.87687 & 0.0000 \\
At most 1 & 0.608130 & $24.35748^{*}$ & 27.58434 & 0.1227 \\
At most 2* & 0.560634 & $21.38296^{* *}$ & 21.13162 & 0.0461 \\
\hline
\end{tabular}

Table 3. Results of VECM granger causality tests.

\begin{tabular}{|c|c|c|c|c|c|c|c|c|c|c|c|}
\hline \multirow{2}{*}{ Dep. Var } & \multicolumn{6}{|c|}{ Independent variables } & \multicolumn{5}{|c|}{ Inferences } \\
\hline & $\mathrm{Y}$ & LFP & GCF & MDL & CPI & ECT & $\mathrm{Y}$ & LFP & GCF & MDL & CPI \\
\hline $\mathbf{Y}$ & - & $8.419778^{\star * \star}$ & 2.469995 & 0.099294 & 0.274741 & $12.25822^{\star}$ & $\mathrm{N}$ & $\mathrm{X}$ & $\mathrm{N}$ & $\mathrm{N}$ & $\mathrm{N}$ \\
\hline LFP & $12.2069^{*}$ & - & 4.370929 & 0.110837 & 0.516652 & $15.0261^{\star *}$ & $\mathrm{X}$ & $\mathrm{N}$ & $\mathrm{N}$ & $\mathrm{N}$ & $\mathrm{N}$ \\
\hline .GCF & 3.769209 & 4.323487 & - & 0.514526 & 0.529769 & 6.699529 & $\mathrm{~N}$ & $\mathrm{~N}$ & $\mathrm{~N}$ & $\mathrm{~N}$ & $\mathrm{~N}$ \\
\hline MDLN & $5.870469^{\star *}$ & $7.03527^{\star \star}$ & 3.680091 & - & $15.6691^{\star * *}$ & $23.87051^{\star}$ & $\mathrm{X}$ & $\mathrm{X}$ & $\mathrm{N}$ & $\mathrm{N}$ & $\mathrm{X}$ \\
\hline CPI & $14.81459^{* * *}$ & $16.34890^{*}$ & $5.072941^{\star *}$ & 0.612418 & - & $26.07421^{*}$ & $\mathrm{X}$ & $\mathrm{X}$ & $\mathrm{X}$ & $\mathrm{N}$ & $\mathrm{N}$ \\
\hline
\end{tabular}

$*, * *, * *$ indicate $10 \%, 5 \%$ and $1 \%$ level of significance. $\mathrm{X}$ indicates presence of causality; $\mathrm{N}$ indicates absence of causality.

does labour force participation Granger causes economic growth (Y $\leftrightarrow$ LFP). The results are not quite surprising in the case of Nigeria, where human capital contributed significantly towards increasing the level of economic growth through increasing productivity.

In the third segment of the table, the results show that there is unidirectional causality between man-day lost (that is industrial action) and economic growth. It was revealed that causality runs from economic growth $(\mathrm{Y})$ to industrial action indicator at $\mathrm{p}<0.05$ level of significant $(\mathrm{Y} \rightarrow \mathrm{MDL}$ ). The results further reveal the existence of unidirectional causality running from labour force participation to industrial action indicator at 5\% level of significance (LFP $\rightarrow$ MDL). The results also uncover the unidirectional causality from consumer price index to man-day lost at $1 \%$ level of significance (CPI $\rightarrow \mathrm{MDL}$ ). That is, CPI Granger causes economic growth in Nigeria.

Moreover, the results show that economic growth Granger causes inflation at $\mathrm{p}<0.01$ level of significance ( $\mathrm{Y} \rightarrow \mathrm{CPI}$ ). Hence, economic growth significantly influences inflation rate. It was also revealed from the same Table 3 that causality runs from LFP to CPI at $1 \%$ level of significance (LFP $\rightarrow$ CPI). This implies that labour force participation Granger causes Consumer price index. The cau- 
sality runs from gross capital formation to consumer price index at $\mathrm{p}<0.10$ level of significance.

Therefore, this analysis reveals unidirectional causality from labour force participation to economic growth; economic growth Granger causes consumer price index; consumer price index Granger causes industrial action indicator; and economic growth Granger causes man-day-lost (LFP $\rightarrow$ Y; $\mathrm{Y} \rightarrow \mathrm{CPI}$; CPI $\rightarrow \mathrm{MDL}$; $\mathrm{Y} \rightarrow \mathrm{MDL}$ ). On the basis of these results, one can argue that human capital has a significant role in determining the level of economic growth in Nigeria and that the level of growth significantly influences rate of inflation in the country. Furthermore, inflation rate contributed to persistence increase in number of industrial actions occurring in Nigeria. Finally, the results reveal the existence of feedback effect among economic growth, labour force participation, inflation, gross capital formation, and strike action indicator in Nigeria.

In summary, the Granger causality tests revealed that economic growth Granger causes industrial action and not the other way round, which is similar to our expectations but against so scholars view; that is the direction of causality should be other way round. Also, we discovered that economic growth Granger causes inflation. This implies that the past value of economic growth in the country significantly influences Industrial action; and consumer price index, and that increase in inflation rate contributed to increase in man-day lost witnessed in the country. The implication of this is that when prices of goods and services go up, labour agitates for higher income which may also lead to higher industrial action. The findings conform to the work of Vikesh and Subrina (2004) [38] that the causality between economic growth and inflation ran one-way from economic growth to inflation. Nigeria is a developing economy with high prospect for economic growth and development. With any little significant changes in growth, individual tends to feel such changes in their personal income and the only noticeable measure with which they present their agitation is to propose strike action. There is need for the country to find some alternative ways of reducing industrial strike in the country that could act as hindrances in achieving the desired like Vision 20:2030.

\section{Conclusion}

The Causality between industrial action and economic growth in Nigeria was investigated using VECM Granger Causality method. Industrial action and economic growth series were non-stationary series at level but stationary at first differencing. The co-integration test results conducted indicating a long-run relationship between the two series. The results reveal that increase in economic growth caused increase in industrial action, and more importantly, growth in GDP with high inflation rate significantly increases industrial action in Nigeria. The paper concluded that persistent increase in the industrial action over argument on increment of salary or other welfare benefiting packages to workers from either employer or government led to a greater distortion in Nigerian economy and Man day lost. For future research, the deficiency of this article is 
the data availability which constraint authors from considering another measure of industrial action for results comparison.

\section{Conflicts of Interest}

The authors declare no conflicts of interest regarding the publication of this paper.

\section{References}

[1] Akkerman, A.A. and Torenvlied, R. (2014) Conflict in Collective Bargaining: The Role of Union and Firm Negotiators' Perceptions of Bargaining Power and Wage Bargaining Space. Work Employment and Society.

[2] Akanbi, L.B. and Akinlo, A.E. (2017) Effects of Strike Action on Economic Growth in Nigeria (1986-2013). Ife Journal of Economics and Finance, 6, 50-62.

[3] Snyder, D. (1975) Industrial Setting and Industrial conflict: Comparative Analysis of France, Italy and United State. American Sociological Review, 40, 259-278. https://doi.org/10.2307/2094458

[4] Ann, H. and Nelson, P. (2004) Strike Activity under Enterprise Bargaining: Economics or Politics? Australian Journal of Labour Economics, 7, 439-457.

[5] Geraghty, T.M. and Wiseman, T. (2007) Conflict and Compromise: Changes in U.S. Strike Outcomes, 1880 to 1937. Working Paper.

[6] Chan, C.K. (2009) Strike and Changing Workplace Relations in a Chinese Global Factory. Industrial Relations Journal, 40, 60-77. https://doi.org/10.1111/j.1468-2338.2008.00513.x

[7] Ige, A.K. (1998) An Empirical Study of the Factors Influencing Industrial Strike in Nigeria (1970-1995). A Thesis Submitted to the Department of Economics, Obafemi Awolowo University, Ile-Ife.

[8] Owoseni, O.O. (2007) An Examination of Some Determinant of Industrial Conflict in Employee-Employer Relationship. Working Paper, 1-18.

[9] Osabuohien, E.S.C. and Ogunriola, I.O. (2011) Causes and Effects of Industrial in Nigeria: Some Empirical Clarifications. Labour Law Review, 1, 75-93.

[10] Osabuohien Evans, S.C. (2009) Industrial Conflicts and Healthcare Provision in Nigeria. An Interdisciplinary Discourse on Human Condition. Labour Law Review, $1,75-93$.

[11] Okuwa, O.B. and Campbell, O.A. (2011) Influence of Strike on the Choice of Higher Education Demand in Oyo State, Nigeria. Journal of Emerging Trend in Economics and Management Science, 2, 275-280.

[12] Agba, A.M., Ogaboh and Ushie, E.M. (2012) Wage Differentiations and Industrial Disputes in Nigerian Hospitals. Journal of Business and Management, 11, 1-12. https://doi.org/10.9790/487X-1150112

[13] Ezeagba, E.C. (2014) Effects of Strike Cost on Economic Development in Nigeria. International Journal of Arts and Humanities, 3, 26-34. https://doi.org/10.4314/ijah.v3i3.3

[14] Galambos, P. and Evans, E.W. (1966) Work-Stoppages in the United Kingdom 1951-1964: A Quantitative Study. Bulletin of the Oxford University, Institute of Economics and Statistics, 28, 33-55. https://doi.org/10.1111/j.1468-0084.1966.mp28001003.x

[15] Hibbs, D.A. (1976) Industrial Conflict in Advanced Industrial Societies. American 
Political Science Review, 70, 1033-1058. https://doi.org/10.2307/1959373

[16] Kyuhan, B. (1993) A Theoretical Approach to Industrial Conflict in a Rapidly Industrializing Country; the Korea Case. Journal of Population and Development, 22, 47-59.

[17] Ige, A.K. and Sowunmi, F.A. (2012) Impact of Trade Dispute on Nigerian Economy. African Journal of Global Issue, 1, 21-47.

[18] Diduch, A.M. (1998) Global Strike Patterns, Macroeconomic Variables, and Industrial Relations. International Review of Comparative Public Policy, 10, 3-34.

[19] Greenbaum, J.S. (1972) The Rebellious Rank and File. Personnel, 49, 20-25.

[20] Weil, N.D. (2011) Economic Growth. Second Edition, Brown University, Providence, 228-232.

[21] Beggs, J.J. and Chapman, B.J. (1987) Declining Strike Activity in Australia, 1983-85: An International Phenomenon. Economic Record, 63, 330-339. https://doi.org/10.1111/j.1475-4932.1987.tb00666.x

[22] Morris, A. and Wilson, K. (1994) An Empirical Analysis of Australian Strike Activity: Further Evidence on the Role of the Prices and Incomes Accord. Economic Record, 70, 183-191. https://doi.org/10.1111/j.1475-4932.1994.tb01837.x

[23] Bhorat, H., Jacob, E. and Westhuizen, C.V.D. (2013) Do Industrial Disputes Reduce Employement? Africa Growth Initiative at Brookings. Working Paper 6.

[24] Seniwoliba, A.J. (2013) Ghana's Numerous Workers Strikes; a Cause for Concern. Merit Research Journal of Education and Review, 1, 159-171.

[25] Odeku, K.O. (2014) An Overview of the Strike Phenomenon in South Africa. Mediterranean Journal of Social Sciences, 5, 695-702. https://doi.org/10.5901/mjss.2014.v5n3p695

[26] Maueon, A. and Vannetelbosch, V.J. (2002) Market Competition and Strike Activity. International Journal of Industrial Organization, 21, 737-758. https://doi.org/10.1016/S0167-7187(02)00092-9

[27] Barro, R.J. and Sala-i-martins, X. (2009) The Economic Growth. Second Edition, PHI Learning Private Limited, New Delhi, 28, 70-79.

[28] Anyim, C.F., Chidi, O.C. and Ogunyomi, O.P. (2012) Trade Disputes and Settlement Mechanisms in Nigeria: A Critical Analysis. Interdisciplinary Journal of Research in Business, 2, 155. https://doi.org/10.5430/ijba.v2n4p155

[29] Ige, A.K. and Sowunmi, F.A. (2013) An Empirical Study of the Factors Influencing Industrial Conflicts in Nigeria (1980-2010). European Journal of Humanities and Social Sciences, 10, 423-439.

[30] Fajana, S. (2006) Industrial Relations in Nigeria: Theory and Features. 3rd Edition, Labofin and Company, Lagos.

[31] Oyeniran, O. (2013) ASUU Strike: Causes and Implication of Education Worker's Strike.

[32] Omotosho, B.J. (2007) Privatization and Challenges of Workers' Welfare: A Case Study of PHCN Workers in Ado Ekiti. Labour Law Review, 1, 116-133.

[33] Ajayi, J.O. (2014) ASUU Strikes and Academic Performance of Students in Ekiti State University Ado-Ekiti Department of Sociology, Faculty of the Social Sciences, Ekiti State University Seminar.

[34] Hurlin, C. and Vecent, B. (2001) Granger Causality Tests in a Panal Data Models with Fixed Coefficient. Eurossco Working Paper 2001-09, University Paris IX.

[35] Engle, R.F. and Granger, C.W.J. (1987) Co-Integration and Error Correction: Rep- 
resentation, Estimation and Testing. Econometrica, 55, 251-276.

https://doi.org/10.2307/1913236

[36] Lütkepohl, H. (2005) New Introduction to Multiple Time Series Analysis. Springer, Berlin.

[37] Johansen, S.A. and Juselius, K. (1990) Maximum Likelihood Estimation and Inference on Cointegration with Application to the Demand for Money. Oxford Bulletin of Economics and Statistics, 52, 169-209. https://doi.org/10.1111/j.1468-0084.1990.mp52002003.x

[38] Gokal, V. and Hanif, S. (2004) Relationship between Inflation and Economic Growth in Kenya. 